\title{
Suction Monitoring and Stability of Volcanic-Residual Soil Slope during Rainfall
}

\author{
Muntohar, A.S.1*, Fata, N.1, Jotisankasa, A. ${ }^{2}$, and Yang, K-H. ${ }^{3}$
}

\begin{abstract}
Some slopes in Yogyakarta, Indonesia, were covered by volcanic soil of the quaternary deposit of Merapi volcano. Typically, the soil layers of the slope consist of fine sand or silty sand. During the wet season (November - February), the slope is prone to instability due to rainfall infiltration. This paper presents the field suction monitoring of silty-sand slope. A $2.57 \mathrm{~m}$ high slope at Universitas Muhammadiyah Yogyakarta campus was instrumented with a mini tensiometer, moisture probe, and rain gauge to study the effect of suction on the slope stability during rainfall in wet season. The investigation shows that the rainfall decreases the suction and increase the moisture of soil. This situation leads to slope instability. The factor of safety fluctuates corresponding to the rainfall intensity. The lowest factor of safety was attained on 30 December, in which the rainfall intensity is the highest, i.e. $48 \mathrm{~mm} /$ day.
\end{abstract}

Keywords: Suction; rainfall; volcanic soil; slope stability; unsaturated soil.

\section{Introduction}

Many slopes in Indonesia are covered by volcanicresidual soil, which comprises of loose structure. Thus, the slopes are prone to failure due to rainfall. Lessen research has been conducted on the saturatedunsaturated behavior of the volcanic soil slopes in Indonesia [1]. Typically, rainwater easily infiltrates into the soil and induces landslides. Slope stability analysis is needed to determine the level of risk of a landslide slope by analyzing the value of the safety factor. It is common to evaluate the slope stability at the critical condition when it is in the fully saturated condition. At this condition, a positive pore water was generated along the slope depth. In contrast, the stability at the dry condition is usually related to a negative pore water pressure. The negative pore water pressure or suction plays a significant role in controlling the slope stability [2]. The suction easily decreases during the high-intensity rainfall and induces a slope failure [3].

Many studies show a complex relationship between slope instability and rainfall patterns around the world [4]. Slope monitoring by measuring the pore water pressures, soil moisture, groundwater level fluctuation, and rainfall intensity is the standard method applied to evaluate the instability of slope [5], and in some cases total station [6,7].

${ }^{1}$ Department of Civil Engineering, Universitas Muhammadiyah Yogyakarta, Jl. Brawijaya Tamantirto, Yogyakarta, 55183, INDONESIA.

2 Department of Civil Engineering, Kasetsart University, 50 Ngam Wong Wan Rd, Bangkok, 10900, THAПAND.

${ }^{3}$ Department of Civil Engineering, National Taiwan University, No. 1, Section 4, Roosevelt Rd, Taipei, 10617, TAIWAN.

*Corresponding author; Email: muntohar@umy.ac.id

Note: Discussion is expected before November, $1^{\text {st }} 2020$, and will be published in the "Civil Engineering Dimension", volume 23, number 1, March 2021.

Received 10 April 2020; revised 25 April 2020; accepted 19 June 2020
Understanding the slope response during rainfall is a key to assess the mechanism of slope failure. Shallow failure is the typical failure in many unsaturated slopes. The failure zone commonly occurs in the transient region, which is actively affected by the infiltration and evaporation [3,8]. It is essential to measure the field pore water pressure to have a better evaluation of slope stability. This paper presents the results of suction monitoring in an instrumented man-made slope at Universitas Muhammadiyah Yogyakarta (UMY) campus (Figure 1). The study aims to measure the suction and to investigate the effect of suction fluctuation on the slope stability during rainfall. Numerical analyses of rainfall infiltration and slope stability was performed to verify field measurement of the suction and variation of safety factor during the rainfall.

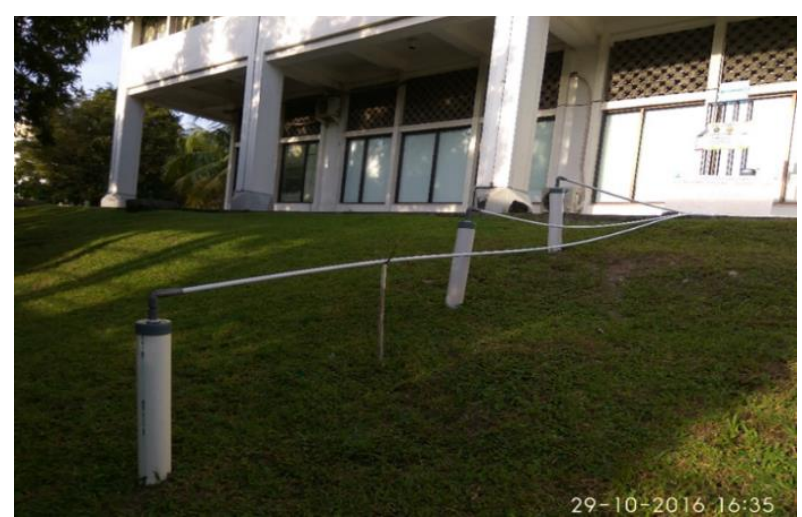

Figure 1. The Condition of the Monitored Slope at UMY Campus

\section{Method and Analysis}

\section{Slope Properties}

The inclination of the slope is measured at about $18^{\circ}$. Figure 2 shows the condition of the monitored slope and the position of the tensiometer. The Kasetsart 
University (KU) tensiometer, which able to measure the pore water pressure in the range of $-100 \mathrm{kPa}$ to $600 \mathrm{kPa}$, was used to monitor the pore water pressure in the field $[9,10]$. The tensiometer were installed at the depths of $0.5 \mathrm{~m}$ (labeled TA), $1 \mathrm{~m}$ (TB), and $1.5 \mathrm{~m}$ (TC). The monitoring was conducted from 15 to 31 December 2016. The initial suction, moisture, and degree of saturation were measured immediately after installation of the PVC pipes (see Fig. 2) on 11 December 2016. The initial moisture and degree of saturation were measured by the HI98195 Multiparameter of HANNA instrument [11].

The slope was covered with homogenous silty-sand soil about $2.6 \mathrm{~m}$ thick, the soil comprised of $69 \%$ of sand particles, and $31 \%$ of silt-size particles. Thus, the soil is classified as silty-sand soil, which symbolized with SM, according to Unified Soil Classification System (USCS) [12]. The soil's origin is the quarternary volcanic residual sand deposit of Merapi volcano in Yogyakarta, Indonesia. The soil properties are presented in Table 1. The undisturbed soil samples were collected to determine the shear strength parameter using triaxial and direct shear test.

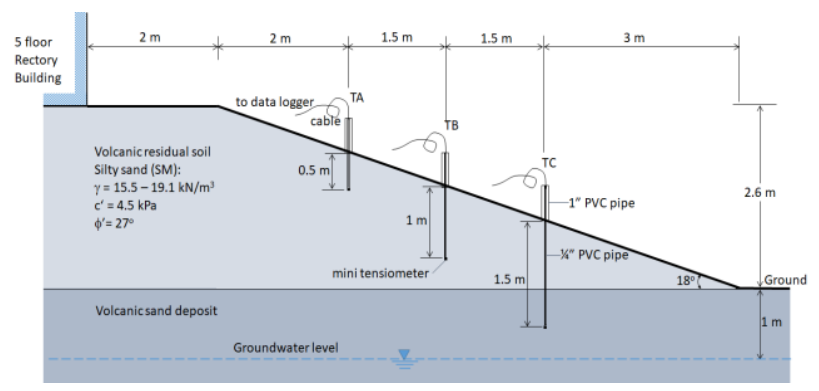

Figure 2. Cross-section of the Slope, and Arrangement of the Tensiometer Installation

Table 1. Soil Properties of the Monitored Slope

\begin{tabular}{ll}
\hline Properties & Value \\
\hline Specific gravity, $\mathrm{G}_{\mathrm{s}}$ & 2.61 \\
Unit weight, $\gamma\left(\mathrm{kN} / \mathrm{m}^{3}\right)$ & $15.5-19.1$ \\
Natural moisture content wN $(\%)$ & $14-16$ \\
Shear strength parameter & \\
Triaxial UU: Cohesion, c $(\mathrm{kPa})$ & 4.5 \\
$\quad$ Internal friction angle, $\phi\left({ }^{\circ}\right)$ & 27 \\
$\quad$ Degree of saturation $\mathrm{S}_{\mathrm{r}}$ & 0.7 \\
Direct shear test: Cohesion, c $(\mathrm{kPa})$ & 15 \\
$\quad$ Internal friction angle, $\phi\left({ }^{\circ}\right)$ & 32 \\
Saturated coefficient of permeability, $\mathrm{k}_{\mathrm{s}}(\mathrm{m} / \mathrm{s})$ & $6.27 \times 10^{-6}$ \\
\hline
\end{tabular}

\section{Soil-water Characteristic Curve (SWCC) Mea- surement}

The soil-water characteristic curve (SWCC) is measured to obtain the unsaturated strength parameter. In this study, SWCC was determined using a KU miniature tensiometer. Figure 3 illustrates the schematic cross-section of the SWCC test and tensiometer. The undisturbed soil about $63 \mathrm{~mm}$ in diameter and 20 mm thickness were tested for SWCC using the method as explained by Jotisankasa and Mairaing [9]. The method involved gradually wetting soil samples in which at each stage suction of the sample was monitored until equilibrium was reached. A minimum curing period of about 2-3 days between each increment was allowed for equilibration of the suction throughout the sample, carefully wrapped to prevent evaporation. The SWCC and hydraulic conductivity functions were calculated by Mualem van Genuchten model as in Equations 1 and 2 [13,14]. Figure 4 shows the SWCC and hydraulic conductivity function of the soils.

$$
\begin{aligned}
& \theta(\psi)=\theta_{r}+\left(\theta_{s}-\theta_{r}\right)\left[1+|\alpha \psi|^{n}\right]^{-m} \\
& k(\psi)=k_{s} S_{e}^{l}\left[1-\left(1-S_{e}^{1 / m}\right)^{m}\right]^{2} \\
& S_{e}=\left[\frac{\theta(\psi)-\theta_{r}}{\theta_{s}-\theta_{r}}\right]
\end{aligned}
$$

and, $m=1-1 / n$

In which $S_{e}$ is effective degree of saturation, $\psi$ is the suction head; $\alpha$ is the inverse of the air-entry value (or bubbling pressure); $n$ is pore-size distribution index; $\theta_{r}$ and $\theta_{s}$ denote the residual and saturated water contents respectively; $k_{s}$ is the saturated hydraulic conductivity. The parameters $\alpha$ and $n$ are empirical coefficients obtained from the best-fit of the laboratory data.

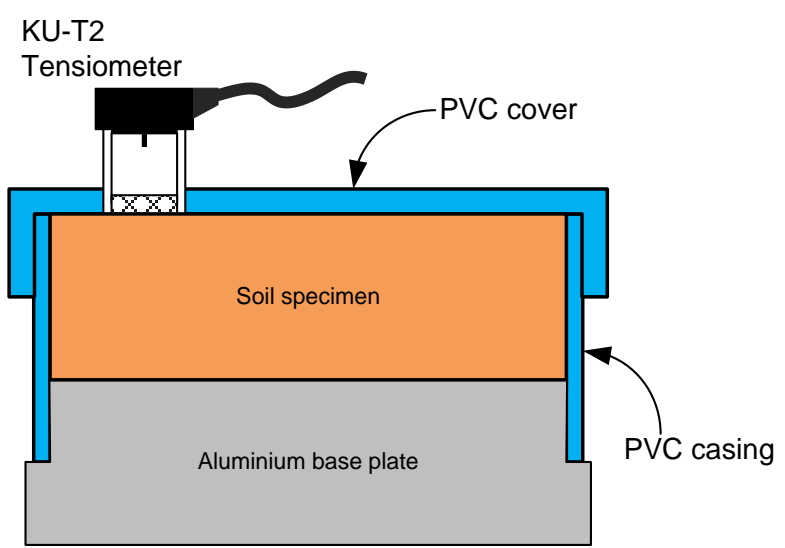

(a)

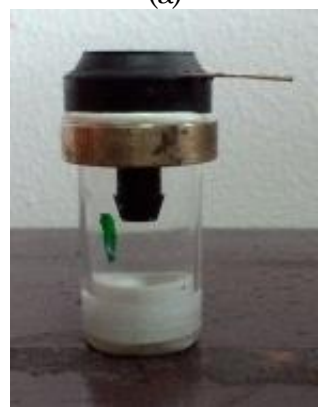

(b)

Figure 3. (a) Schematic Cross-section of SWCC Test using KU Tensiometer, (b) the KU Tensiometer for SWCC Test 


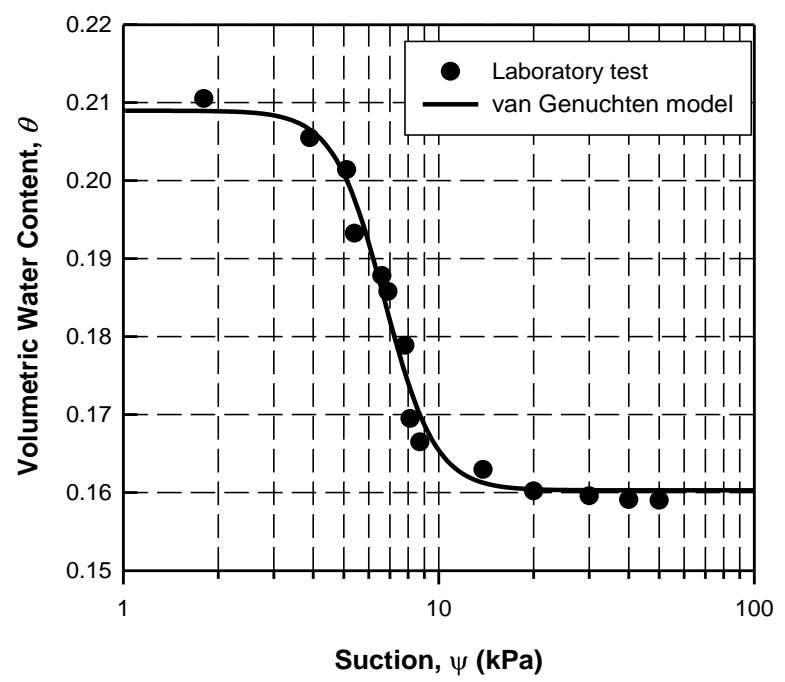

(a)

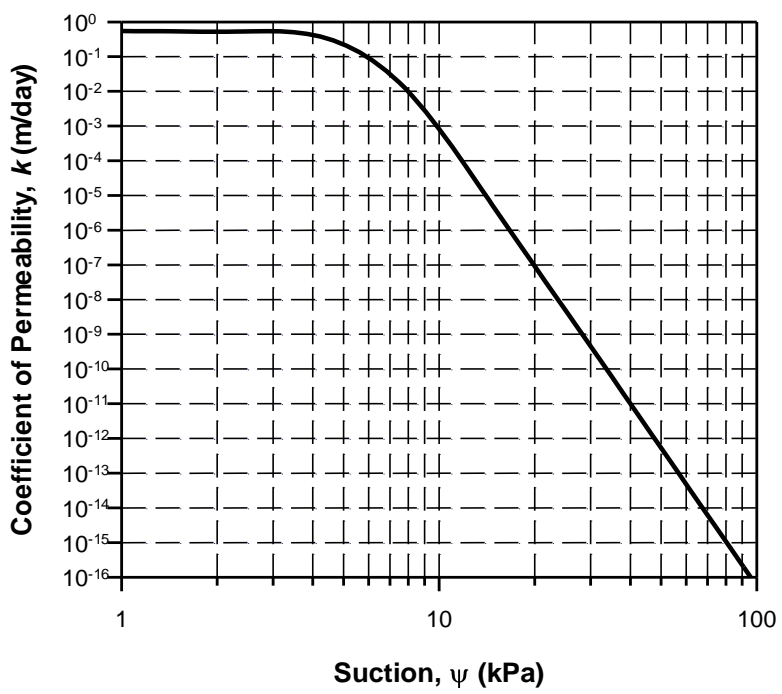

(b)

Figure 4. The Hydraulic Properties of Soil (a) Soil-water Characteristics Curve, (b) Coefficient of Permeability Function

\section{Slope Stability Analysis}

Two-dimensional slope stability analysis utilized SLOPE/W to determine the factor of safety with timevarying [15]. The factor of safety was determined by using limit equilibrium Morgenstern-Price. A finite element software SEEP/W was used to simulate the change of porewater pressure during a transient rainfall infiltration [16]. The water pressure was retrieved from the SEEP/W results to calculate the factor of safety of the slope during the rainfall. The boundary conditions of the slope are illustrated in Figure 5. For the transient seepage analysis, boundary conditions were added to the slope model. Nonponding boundary conditions have been used to avoid excessive accumulation of rainfall on the slope surface. Flow boundary $q$ equal to the desired precipitation, and duration was applied to the slope surface. The accumulated rainfall reached $98 \mathrm{~mm}$ with the highest daily rainfall intensity $48 \mathrm{~mm}$ was recorded on 30 December 2016. The initial condition was generated from the groundwater table with a limitation of initial suction on the surface about 21 $\mathrm{kPa}$.

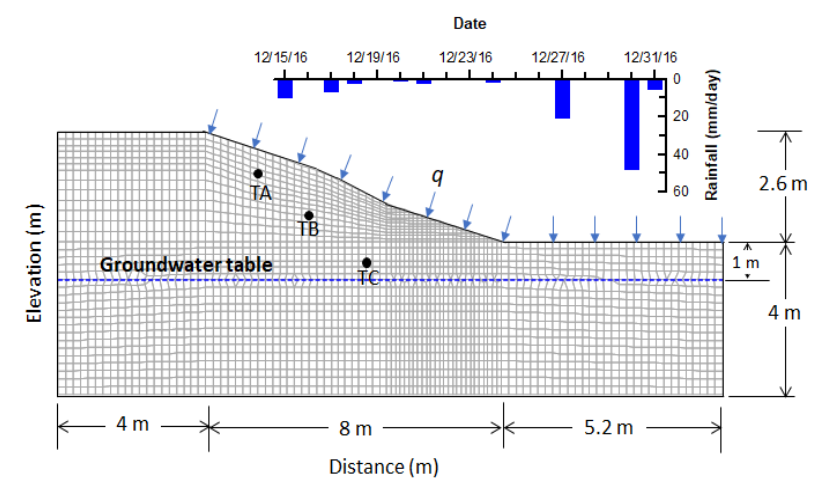

Figure 5. The Finite Element Model of the Slope and the Precipitation Record

\section{Results and Discussion}

\section{Variation of Porewater Pressure}

Initial suction and moisture content at the slope surface were measured about $21 \mathrm{kPa}$ and $23 \%$, respectively. The suction gradually decreases to $7.9 \mathrm{kPa}$, $4.5 \mathrm{kPa}$, and $1.5 \mathrm{kPa}$ respectively at tensiometer TA $(\mathrm{z}=0.5 \mathrm{~m}), \mathrm{TB}(\mathrm{z}=1 \mathrm{~m})$, and $\mathrm{TC}(\mathrm{z}=1.5 \mathrm{~m})$ as shown in Fig. 6a. Whereas the moisture content increases with the depth as shown in Figure 6b. At the tensiometer TB and TC, the suction approached near saturation (see Figure 6c). The surface was initially unsaturated, with the degree of saturation of 0.78 . The degree of saturation increased with the depth and reaches near fully-saturated at a depth of $1.5 \mathrm{~m}$ below the slope surface. The groundwater level fluctuated between $0.8 \mathrm{~m}$ to $1 \mathrm{~m}$ below the ground surface, as indicated in Figure 2. The tensiometer tip at TC was about $0.3 \mathrm{~m}$ to $0.5 \mathrm{~m}$ above the groundwater table. This condition indicates that the capillarity effect from the perched groundwater table might exist due to antecedent rainfall. It is noted that the rain gauge error for two weeks from 1-14 December, so there was no rainfall data in this period. However, the rainfall observation from the Tropical Rainfall Measuring Mission (TRMM) satellite at the location indicates precipitation data available in 1-14 December (Figure 7). The antecedent rainfall in 1-9 December might moisten the soil layers and caused a high degree of saturation near the tensiometer TB and TC.

Figure 8a shows the variation of suction with the elapsed time of rainfall. At the tensiometer TA $(z=0.5$ $\mathrm{m})$, the suction varies from 6.4 to $11.7 \mathrm{kPa}$, and the suction ranges from 2.8 to $6.3 \mathrm{kPa}$ at tensiometer $\mathrm{TB}$ $(\mathrm{z}=1 \mathrm{~m})$. Meanwhile, tensiometer TC $(\mathrm{z}=1.5 \mathrm{~m})$ measures suction from 1.7 to $3.1 \mathrm{kPa}$. The figure illustrates that the suction decreases when the rainfall intensity increases. It is a typical response of 
slope that the rainwater decreases the suction, as observed by Rahardjo et al. [17]. Rainfall intensity tends to decrease from 15 to 26 December, and no rainfall is recorded in $16,19,22,25$, and 26 December. In the meantime, the suction at tensiometer TA increases from $8.1 \mathrm{kPa}$ to $11.7 \mathrm{kPa}$. But the increase of the suction is less at the $1 \mathrm{~m}$ and $1.5 \mathrm{~m}$ deep. At near slope surface, the suction in root-permeated soil increases mightbe caused by evapotranspiration and climate condition [2,18]. During the rainfall period from 27-30 December, the tensiometer TA records a rapid suction reduction from $11.7 \mathrm{kPa}$ to $6.4 \mathrm{kPa}$. But, the tensiometer TB and TC responds to a delayed decrease of the suction after 30 December. The delay response of the suction change might be controlled by the water storage capacity of the soil profile. The delay response in the decrease of the suction at a greater depth was also observed by Zhan et al. [18] and Lim et al. [2]. A decrease in suction was probably due to the percolating of rainwater from the infiltration. Another factor that affects the suction reduction at a depth of $1 \mathrm{~m}$ and $1.5 \mathrm{~m}$ was the development of a perched water table in the slope.

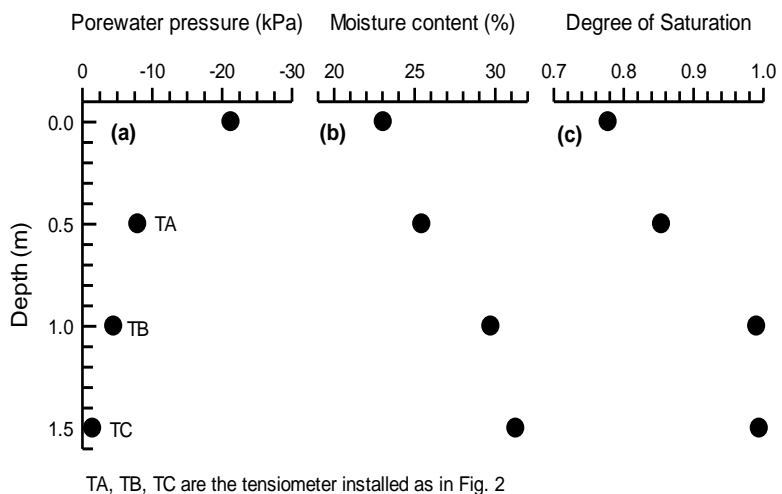

Figure 6. The Initial Condition at the Slope (a) Suction, (b) Moisture Content, and (c) Degree of Saturation.

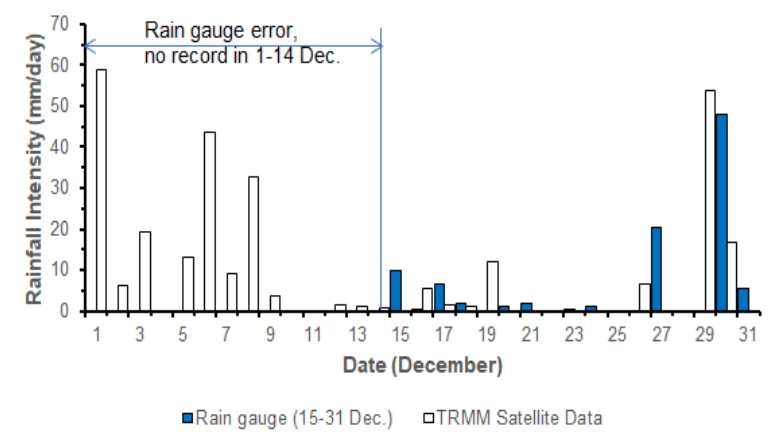

Figure 7. Comparison of Rainfall Data from TRMM Satellite and Rain Gauge Measurement

The fluctuation of soil moisture during the rainfall is shown in Figure 8b. The figure shows that the variation of soil moisture relates to the suction (see Equation 1). The soil moisture increases as the depth increases, and near to the toe of the slope. A considerable moisture change is clearly observed at a depth of 0.5 $\mathrm{m}$ and $1 \mathrm{~m}$, while the soil moisture slightly changes at a depth of $1.5 \mathrm{~m}$. At the near ground surface, rainfall pattern alters the flux boundary conditions such as infiltration and evapotranspiration $[4,19]$. As a result, the soil moisture simply fluctuates due to the variation of rainfall intensity. As rainwater infiltrates through the soil pores, the water content of the soil will increase, and the groundwater table would be raised. It is interesting to know that the soil moisture at a depth of $1 \mathrm{~m}$ slightly decreases after rainfall on 27 December; in the meantime, the soil moisture increases at a depth of $0.5 \mathrm{~m}$. Rainwater needs a certain magnitude of infiltration rate to penetrate into subsurface soil. The seepage simulation using SEEP/W indicates that the rainwater runoff is greater than the infiltrated rainwater, as shown in Figure 9. Another factor that affects the infiltration is a damming effect from the grass cover on the slope surface [3,20]. The damming would delay the percolation and increase of soil moisture. The variation of soil moisture due to rainfall was also controlled by initial moisture prior to the rainfall. As in Figure $6 \mathrm{~b}$, the initial water content at depth $1.5 \mathrm{~m}$ approaches the maximum storage capacity for saturation condition (see Figure 6c). This condition does not much alter the soil moisture at a depth of $1.5 \mathrm{~m}$.

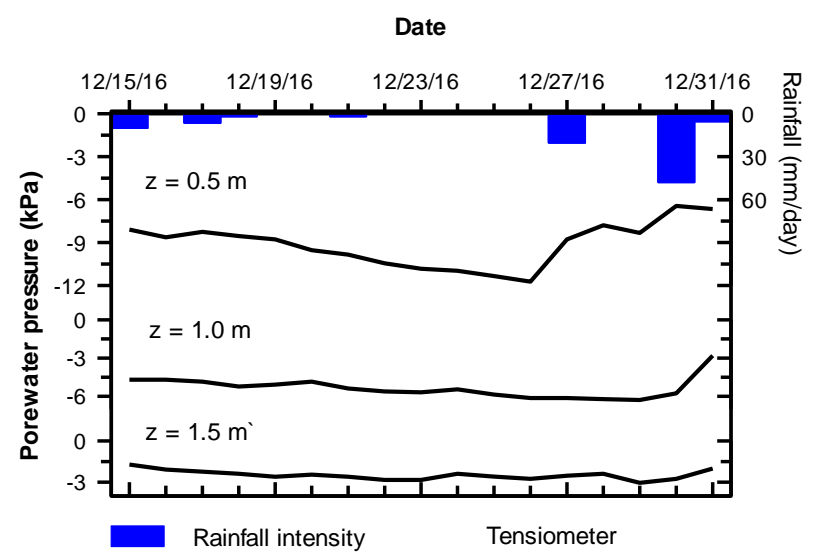

(a)

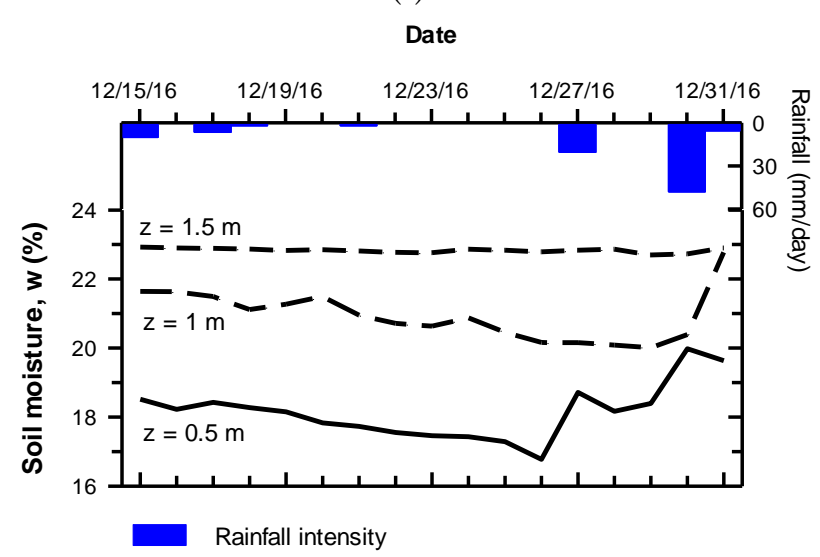

(b)

Figure 8. Variation of the Porewater Pressure from Numerical Simulation and Tensiometer Measurement 


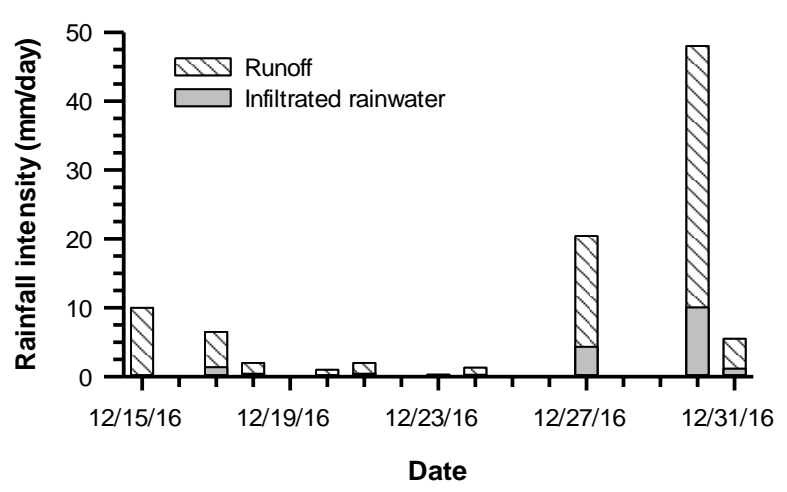

Figure 9. Runoff and Infiltration Rate from Numerical Seepage Simulation

\section{Simulation of the Porewater Pressure Profile}

The limitation of this research is that the tensiometer layout at TA, TB, and TC cannot present the porewater pressure profile along the depth. Porewater profiles under transient seepage conditions were simulated using SEEP/W. The variation of porewater pressure profile from the numerical analysis is shown in Figure 10. The porewater pressure from the tensiometers observation was also plotted in the profile. The figures show a wetting front during the transient rainfall infiltration. As water infiltrated into the soil, the length of the transient zone increases and the infiltrating rainwater wetted the wetting zone, which subsequently flow downward in the soil profile [21]. The wetting front depth is observed $1.4 \mathrm{~m}, 1.2 \mathrm{~m}$, and $0.8 \mathrm{~m}$ deep respectively at TA, TB, and TC location. This result in Figure 10a confirmed that the position of tensiometer TA is in a transient zone. In this zone, the suction is strongly fluctuated and influenced by the change of boundary flux on the surface [8]. The suction observation at TB is located in the wetting zone (see Figure 10b). At this water flow regime, the moisture accumulates in the near-surface region before advancing down through the soil as a distinct wetting front. Hence, only heavy or continuous rainfall can advance to moisten and saturate the wetting front [22]. This mechanism would delay the increase in soil moisture at a deeper soil layer. Fig. 10c indicates that the tensiometer TC is positioned at the hydrostatic line that is influenced by the raised water table during the transient rainfall infiltration.

\section{Slope Stability}

Figure 11 shows the distribution of porewater pressure and slope stability for various times of rainfall. The figure presents that the circular slip surface lies from the top slope and move downward to the base layer. The porewater distribution in Figure 11 (left) depicts the development of porewater pressure with the time of rainfall. Initially, the negative porewater pressure ranging from $-25 \mathrm{kPa}$ to $-5 \mathrm{kPa}$ was dispersed throughout the slope. The rainfall infiltration increases the porewater pressure, as shown in Figure 11. The rainfall infiltration would also increase the soil moisture, and change the strength and unit weight of the soil that leads to lowering the factor of safety [23].
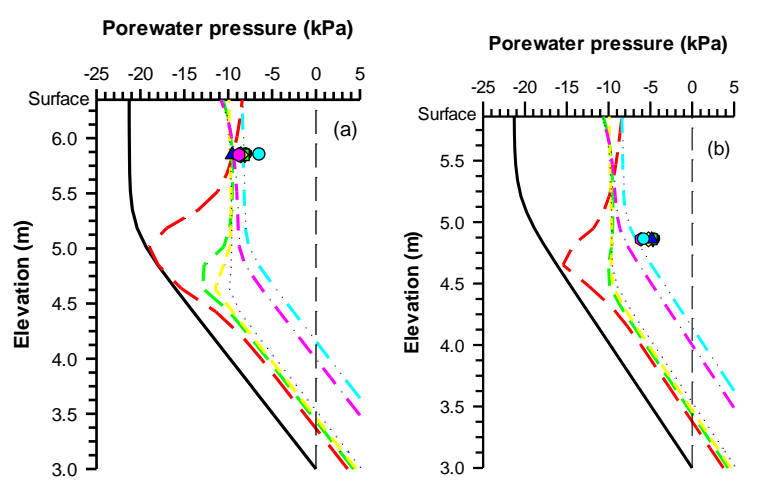

Porewater pressure (kPa)

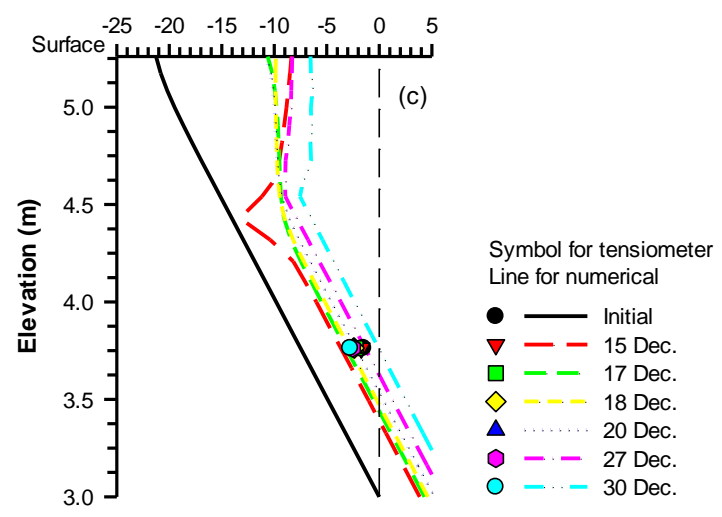

Figure 10. Porewater Pressure Profile from the Numerical Analysis at Different Location of Tensiometer (a) TA, (b) TB, (c) TC

The variation of factor of safety (FS) due to rainfall is given in Figure 12. The FS decreases with an increase in the duration of rainfall. The minimum FS (FS $\left.{ }_{\text {min }}\right)$ was attained on 30 December, in which the rainfall intensity is the highest as $48 \mathrm{~mm} /$ day. The factor of safety rapidly decreases when the rainfall intensity is greater than $20 \mathrm{~mm} /$ day as of 27 December and 30 December. If the analysis is advanced to the coming days, the factor of safety recovers after the rainfall ends. Some research, e.g., Tu et al. [3], Rahardjo et al. [17], Rahardjo et al. [5], and Li et al. [24]; concluded that a high rainfall intensity and antecedent rainfall is essential to decrease the factor of safety. Correlation between cumulative rainfall and factor of safety is represented as percent cumulative rainfall $(\mathrm{R})$ and normalized FS $\left(\mathrm{FS}_{\mathrm{n}}\right)$, as given in Figure 13. The trend of $\mathrm{FS}_{\mathrm{n}}$ and $\mathrm{R}$ relationship in Figure 13 can be described by an exponential function as given in Equation 5 .

$F S_{n}=A_{o}+a e^{-b R}$

where, $\mathrm{FS}_{\mathrm{n}}=\mathrm{FS} / \mathrm{FS}_{\min }=$ normalized factor of safety; $\mathrm{R}=$ percent of cumulative rainfall; $\mathrm{A}_{0}, \mathrm{a}$, and $\mathrm{b}=$ fitting parameter. In this study, Equation 5 can be completely written as;

$F S_{n}=0.9844+0.3971 e^{-0.0296 R}$

The Equation can be suggested to evaluate the factor of safety due to rainfall infiltration for a typical slope. 


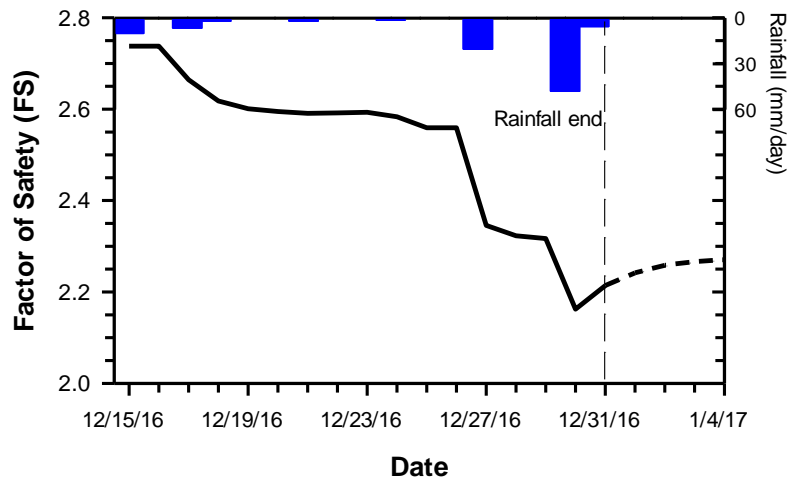

Figure 11. Variation the Factor of Safety with Time

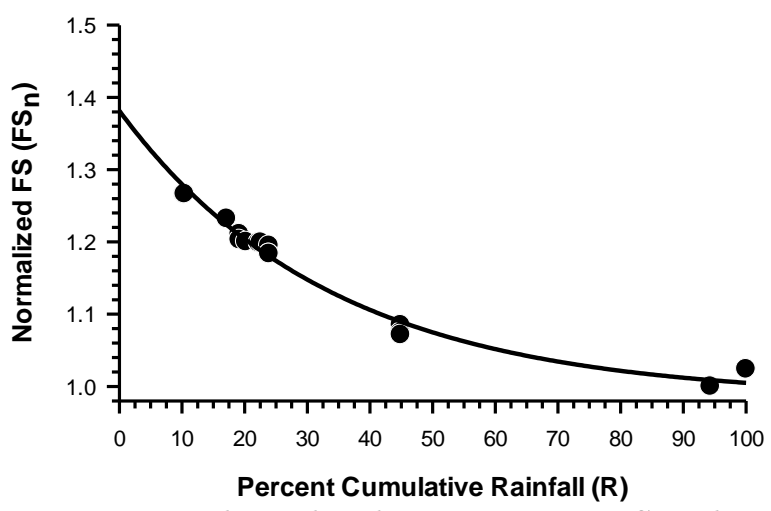

Figure 12. Relationship between Percent Cumulative Rainfall and Normalized Factor of Safety

\section{Conclusion}

Investigation on suction monitoring and numerical analyses at a silty-sand slope have been successfully conducted. The research found that the rainwater infiltrates and increases the moisture of the soil causing suction decreases during the rainfall event. The suction also decreased with depth. The numerical simulation confirmed that a transient zone is observed at a shallow depth of up to $0.5 \mathrm{~m}$. In this water flow regime, the suction quickly changed due to rainfall infiltration. The factor of safety decreases with an increase of the duration of rainfall. The minimum FS (FSmin) was attained on 30 December, in which the rainfall intensity is the highest, that was $48 \mathrm{~mm} /$ day. The factor of safety rapidly decreases when the rainfall intensity is greater than $20 \mathrm{~mm} /$ day as of 27 December and 30 December. This study remarked that a decrease in factor of safety was triggered by increasing the porewater pressure at the top and mid-slope, and perched groundwater table at the toe.

\section{Acknowledgements}

This paper is funded by the Ministry of Research, Technology, and Higher Education, Republic of Indonesia, through a competitive research scheme in 2015-2017. The authors also thank Universitas Muhammadiyah Yogyakarta for financial support through the international collaborative research scheme in 2016-2017.

\section{References}

1. Tohari, A., Sarah, D., and Daryono, M. R., Hydrological Condition Leading to Landslide Initiation, Media Teknik Sipil, 8(2), 2008, pp. 67-76.

2. Lim, T. T., Rahardjo, H., Chang, M. F., and Fredlund, D. G., Effect Of Rainfall on Matric Suctions in a Residual Soil Slope, Canadian Geotechnical Journal, 33(4), 1996, pp. 618-628.

3. Tu, X. B., Kwong, A. K. L., Dai, F. C., Tham, L. G., and Min, H., Field Monitoring of Rainfall Infiltration in a Loess Slope and Analysis of Failure Mechanism of Rainfall-Induced Landslides, Engineering Geology, 105, 2009, pp. 134150.

4. Kristo, C., Rahardjo, H., and Satyanaga, A., Effect of Variations in Rainfall Intensity on Slope Stability in Singapore, International Soil and Water Conservation Research, 5(4), 2017, pp. 258264.

5. Rahardjo, H., Nio, A.S., Harnas, F.R., and Leong, E. C., Comprehensive Instrumentation for Real Time Monitoring of Flux Boundary Conditions in Slope, Procedia Earth and Planetary Science, 9, 2014, pp. 23-43.

6. Afeni, T. B. and Cawood, F. T., Slope Monitoring using Total Station: What Are the Challenges and How Should these Be Mitigated?, South African Journal of Geomatics, 2(1), 2013, pp. 4153.

7. Lienhart, W., Geotechnical Monitoring using Total Stations and Laser Scanners: Critical Aspects and Solutions, Journal of Civil Structural Health Monitoring, 7(3), 2017, pp. 315-324.

8. Rahardjo, H., Satyanaga, A., and Leong, E.-C., Effects of Flux Boundary Conditions on PoreWater Pressure Distribution in Slope, Engineering Geology, 165, 2013, pp. 133-142.

9. Jotisankasa, A. and Mairaing, W., Suction-Monitored Direct Shear Testing of Residual Soils from Landslide-Prone Areas, Journal of Geotechnical and Geoenvironmental Engineering, 136(3), 2010, pp. 533-537.

10. Muntohar, A.S., Influence of the Soil-Water Retention Curve Models on the Stability of Residuals Soils Slope, in Pertemuan Ilmiah Tahunan ke-19 Himpunan Ahli Teknik Tanah Indonesia, Jakarta, 24-25 November 2015 2015: Himpunan Ahli Teknik Tanah Indonesia, pp. 237-244.

11. Muntohar, A. S., Ikhsan, J., and Mukhlisin, M., Studi Dampak Perubahan Iklim Terhadap Longsoran Lereng (Research Report), Unversitas Muhammadiyah Yogyakarta, 2016.

12. ASTM D2487, Standard Practice for Classification of Soils for Engineering Purposes (Unified Soil Classification System), ASTM International, 2006. 
13. van Genuchten, M.T., A Closed-Form Equation for Predicting the Hydraulic Conductivity of Unsaturated Soils, Soil Science Society of American Journal, 44, 1980, pp. 892-898.

14. Mualem, Y., A New Model for Predicting the Hydraulic Conductivity of Unsaturated Porous Media, Water Resources Research, 12(3), 1976, pp. 513-522.

15. GeoStudio, Stability Modeling with SLOPE/W Calgary, Alberta, Canada: Geo-Slope International Ltd., 2004.

16. GeoStudio, Seepage Modeling with SEEP/W Calgary, Alberta, Canada Geo-Slope International Ltd., 2004.

17. Rahardjo, H., Ong, T.H., Rezaur, R.B., and Leong, E.C., Factors Controlling Instability of Homogeneous Soil Slopes under Rainfall, Journal of Geotechnical and Geoenvironmental Engineering, 133(12), 2007, pp. 1532-1543.

18. Zhan, T.L.T., Ng, C.W.W., and Fredlund, D.G., Field Study of Rainfall Infiltration into a Grassed Unsaturated Expansive Soil Slope, Canadian Geotechnical Journal, 44(4), 2007, pp. 392-408.

19. Muntohar, A.S., Ikhsan, J., and Liao, H.J., Influence of Rainfall Patterns on the Instability of
Slopes, Civil Engineering Dimension, 15(2), 2013, pp. 120-128.

20. Yildiz, A., Graf, F., Rickli, C., and Springman, S. M., Assessment of Plant-Induced Suction and Its Effects on the Shear Strength of Rooted Soils, Proceedings of the Institution of Civil Engineers Geotechnical Engineering, 172(6), 2019, pp. 507519.

21. McDougall, J.R. and Pyrah, I.C., Simulating Transient Infiltration in Unsaturated Soils, Canadian Geotechnical Journal, 35(6), 1998, pp. 1093-1100.

22. Lu, N., Kaya, B.S., and Godt, J.W., Direction of Unsaturated Flow in A Homogeneous and Isotropic Hillslope, Water Resources Research, 47(2), 2011.

23. Chatra, A.S., Dodagoudar, G.R., and Maji, V.B., Numerical Modelling of Rainfall Effects on The Stability of Soil Slopes, International Journal of Geotechnical Engineering, 2017, pp. 1-13.

24. Li, A.G., Yue, Z.Q., Tham, L.G., Lee, C.F., and Law, K.T., Field-Monitored Variations of Soil Moisture and Matric Suction in a Saprolite Slope, Canadian Geotechnical Journal, 42(1), 2005, pp. 13-26. 